\title{
PUBLIC ACTION AND THE CONSTRUCTION OF NEW URBAN TERRITORIALITY IN BELO HORIZONTE, BRAZIL
}

\author{
AÇÃO PÚBLICA E A CONSTRUÇÃO DE UMA NOVA TERRITORIALIDADE URBANA \\ EM BELO HORIZONTE (MG)
}

\section{LA ACCIÓN PÚBLICA Y LA CONSTRUCCIÓN DE LA NUEVA TERRITORIALIDAD URBANA EN BELO HORIZONTE, BRASIL}

\section{ABSTRACT}

The article discusses innovative mechanisms of democratic participation arising from Brazilian public policy that articulate relations between government, the private sector, and civil society on questions of territorial development. It focuses on the possibilities and limitations for democratic rearrangements of public spaces and the creation of new participatory tools and languages of public action for the promotion of public policy. The discussion is based on the experience of the city of Belo Horizonte's regionalization led by the municipal government in 2011, in which, the city was divided into 40 areas called "Shared Management Territories." The process, guidelines, and methods are described, and the different cases of dispute, conflict, and cooperation are analyzed to understand the languages of social action and the effects of territorial logic; these work in the construction of spaces and tools, enabling actors to enlarge their political participation, demand, and propose adjustments to public policy.

KEYWORDS: Participatory democracy, participatory tools, shared management territories, territorialization, languages of public action.

Zilma Borges de Souza - zilma.borges@fgv.br

Professor at Fundação Getulio Vargas, Escola de Administração de Empresas de São Paulo - São Paulo, SP, Brazil

Ana Luiza Nabuco - ana.nabuco@ehess.fr

Researcher at École des Hautes Études en Sciences Sociales - Paris, France

João Soares da Silva Filho - jfilho@ufpi.edu.br

Professor at Universidade Federal do Piauí - Teresina - PI, Brazil

Rodrigo Nunes Ferreira - rodrigonunesferreira@gmail.com

Doctoral student at Universidade Federal de Minas Gerais, Instituto de Geociências - Belo Horizonte - MG, Brasil

Maria Cristina de Mattos Almeida - cristinaalmeida@gmail.com

Master in Public Health at Universidade Federal de Minas Gerais - Belo Horizonte - MG, Brasil

Artigo convidado

ACKNOWLEDGMENTS

The authors would like to thank Coordenação de Aperfeiçoamento de Pessoal de Nível Superior (CAPES) for their financial support within the Doctoral and Post-Doctoral Research Program.

DOI: http://dx.doi.org/10.12660/cgpc.v21n70.64338

Esta obra está submetida a uma licença Creative Commons 


\section{Resumo}

O artigo discute as políticas públicas brasileiras do ponto de vista das articulações entre governo, setor privado e sociedade civil, relacionadas aos mecanismos inovadores de participação democrática. Aborda os rearranjos de espaços públicos e a capacidade de criar novos instrumentos participativos com base nas diferentes linguagens de ação pública. Apresenta as limitações e possibilidades da abordagem territorial nas politićas públicas para incluir a orientação democrática que ultrapasse a perspectıva de território como lócus de implementação, unidade de análise, planejamento e intervenção de políticas setoriais. Presume-se que a abordagem territorial nas politicas públicas objetiva a criação ou o aperfeiçoamento de instrumentos de participação da sociedade civil na condiçáo de agentê capaz de intervir na arena de ação pública. Apresenta-se o caso da regionalização da çidade de Belo Horizonte, liderada pelo governo local em 2011, chamado Territórios de gestão compartilhada, que corresponde ao processo seletivo que dividiu a cidade em 40 áreas. São descritos suas motivacões, as orientações e os métodos adotados. Esse processo envolve disputas, conflitos e fóruns, que foram analisados para entender os efeitos da lógica territorial e como os diversos atores procuram apropriação da politica, além de fazer ajustes que atendam às suas demandas.

Palavras-chave: Democracia participativa, instrumentos participativos, territórios de gestão compartilhada, territorialização, linguagens da ação pública.

\section{Resumen}

El artículo discute las políticas públicas brasileñas desde el punto de vista de las articulaciones entre gobierno, sector privado y sociedad civil, relacionadas con mecanismos innovadores de participación democrática. Aborda reordenamientos de espacios públicos y la capacidad de crear nuevos instrumentos participativos. Presenta las limitaciones y posibilidades del abordaje territorial en las pol íticas públicas para incluir una orientación democrática que rebasa la perspectiva de territorio como locus de implementación, unidad de análisis, planificación e intervención de políticas sectoriales. Se presume que el abordaje territorial en las politicas públicas objetiva la creación o perfeccionamiento de instrumentos de participación de la sociedad civil como agente capaz de intervenir en la arena de acción pública. Se presenta el caso de la regionalización de la ciudad de Belo Horizonte, liderada por el Gobierno Local en 2011, llamado «Territorios de gestión compartida», donde son descritas sus motivaciones, las orientaciones y los métodos adoptados. Como resultado de ese proceso colectivo, la ciudad fue dividida en 40 áreas, denominadas "Territorios de gestión compartida". Ese proceso envuelve disputas, conflictos y foros que fueron analizados para entender los efectos de la lógica territorial y como los diversos actores buscan una apropiación de la politica y hacer ajustes que atiendan a sus demandas.

Palabras clave: Democracia participativa, instrumentos participativos, mecanismos de gestión compartida, regionalización, lenguaje de la acción pública.

\section{INTRODUCTION}

The public action approach to public affairs suggests the importance of considering the relationship between multiple actors inside and outside of government and public administration, in a variety of forms of integration and coordination; these combine different scales of activity (Boussaget, Jacquot, \& Ravinet, 2010; Hassenteufel, 2008). Studies have focused on increasing the understanding of these relationships in complex spaces that suggest new ways of looking at the roles of public and private stakeholders including governments, public agencies, private com- panies, financial institutions, networks, associations, and residents (Lascoumes \& Le Galès, 2004, 2009).

Here it is important to look more closely at decision systems, participation, and governance, in order to analyze processes that cannot be reduced to a simple dispute between the centralization or decentralization of the State's role but which imply the necessity of developing local capacities, cooperation, and administrative structures that can promote democratic and participatory practices. As a result, methodologies have centered on the study of networks, networks, on 
mapping conflicts, and the presence of interest groups being used to visualize the various dimensions of experiences of collective construction (Halpern, et al., 2014). Results point to the importance of new social languages that are present in the public arena and that enlarge spaces and possibilities for public action. Spink (2014) proposes that it is necessary to look at how social action occurs in heterogeneous networks of materialities, socialities, and institutionalities, especially where public policy is not the only language present.

We argue that a territorial approach to understanding socioeconomic dynamics can contribute to delivering a greater sense of legitimacy to local demands, but it also requires proper tools to deal with the perspectives of management, governance, and participation. In this sense, one of the aims of our study is to assess whether the territorial approach to public policy has been able to promote the creation or enhancement of forms of social participation and activation of democratic practices, and has been able to create space for new social languages.

Our empirical focus is the state capital of Minas Gerais, Belo Horizonte, and the creation of the "Shared Management Territories" program. We will discuss the process of formulating this approach to regionalization and the instruments created to implement its goals. The project of institutionalizing the Shared Management Territories coordinated by the Belo Horizonte's City Hall (PBH) between the second half of 2010 and the first half of 2011 divided the city into 40 areas with similar characteristics related to their economic and social aspects as well as to access of urban infrastructure.
This article investigates the new territorial proposal, its guidelines, and the two methodological stages of the work: the use of Skater software for the preliminary definition of regional conglomerates, and the political consensus with civil society around geographical boundaries of the territories. It concludes by looking at the effectiveness and continuity of the original proposal five years after its initial implementation (2011-2016).

The text is divided into five topics, including this introduction. The second topic deals with theoretical aspects of the territorialized public action and regionalization processes. The third describes the two methodological stages of the work for the regionalization of the city of Belo Horizonte. Data are presented in the fourth part, where we analyze the results of regionalization and ways of looking at collective public action trajectories. Finally, the concluding remarks discuss what was learned from the study, its limitations, and possible improvements.

\section{PUBLIC ACTION, REGIONALIZATION, AND TERRITORIALITY}

The recent transformations in public administration in Brazil since the 2000s, especially in the relationship between government and civil society, have led to a more participatory and dialogical management, in which decision-making is exercised by different social actors. New practices of coordination and deliberative forums have gained visibility, especially in the field of social governance that part of the Latin American and French literature has defined as a hybrid space and field of public action (Boussaget, et al. 2010; Hassenteufel, 2008; Spink \& Alves, 2008). 
In Brazil, one of the biggest challenges of programs that articulate multiple actors is how to expand the impact of local actions and break the logic of inequality in the implementation of such policies. Will these new arrangements be able to reorder the power game between actors and networks of social relationships, and generate innovation? Especially important are the permanent adjustments of commitment involved in the renewal of norms, values, and public action, and the ways to develop alliances and shared strategies that are both innovative and appropriate to local cultures of territorial legitimacy. This is where the construction of territoriality becomes an important issue.

\section{The concept of homogeneous regions}

The conceptual debate about "region" has a long history. Correa (2000) presents three main strands of this debate as discussed in the concept of geography.

a) Environmental determinism and the concept of natural region, defined as part of a surface characterized by the uniformity resulting from the combination or integration of elements of nature.

b) The "possibilism" of the nineteenth century French school of geography and the concept of the region as a unique geographical landscape, modeled throughout history by human action from the possibilities offered by the natural environment, and associated with a specific kind of life. c) The New Geography, which emerged in the post-World War II period and introduced discussion of the notion of logical positivism based on mathematics; this redefined the region on the basis of clustering techniques as a set of places where the internal differences between these places are smaller than those between them and any element of another set of locations.

This last current of thought within regional geography allowed an approximation of geographical studies with the studies on regional economy, which expanded in the post-war period driven by the theoretical debate on underdevelopment (Ferreira, 1989). Among economists encouraged by the debate on regional development promoted by authors such as Perroux (1955), Myrdal (1957), Hirschman (1958), Williamson (1965), and Boudeville (1969), the idea of regional planning as a State strategy to overcome regional inequalities gains strength. In turn, this also stimulated further geographic studies of regionalization as an instrument of political and pragmatic action of the State.

In this context of appropriation of the concept of region by planning, Perroux (1955) proposes the classification of regionalization studies into three types:

i) Homogeneous region: based on the possibility of territorial aggregation from uniform characteristics, arbitrarily specified.

ii) Polarized region: based on the hypothesis of spatial polarization due to a force field that is established between production units, urban areas, or industrial clusters. Here, the analysis of production and consumption flows, of intra- and inter-regional connections become important because they reveal the existing networks and hierarchies. The region is considered structurally and functionally heterogeneous, with flows of varying intensity converging on a few poles. 
iii) Planning region: derived from the application of political and administrative criteria during the planning activity. Here, regionalization represents an intentionality of the public authority that claims an understanding of the territory based on the implementation of certain public services, the exercise of regulatory power of the State or, for example, the focus of sectoral policies in a given part of the territory.

\section{THE CASE STUDY: THE NEW REGIONAL- IZATION OF BELO HORIZONTE AND THE METHODOLOGY USED}

In the second half of 2010, the Municipality of Belo Horizonte began to discuss a new proposal for city regionalization, organized around a multidimensional concept of homogeneous areas, later called Shared Management Territories. The goal of the Municipality was to work in such a way that the conditions of life within a conglomerate were similar to each other. It was a concept of region based on homogeneity, so as to deepen the analysis of each cluster and knowledge of their needs, challenges, and intra-urban potential in order to better observe and understand the city.

Using the theoretical framework of Perroux (1955), we could say that the technical stage of the regionalization definition opted for the use of tools based on homogeneity. It basically included using inductive techniques of aggregating areas, based on successive agglomerations supported on the regularities found, according to predefined criteria. For this step of the operation, it used the Skater algorithm to define the agglomerates of homogeneous areas. This choice was based on the need to define, in accordance with the guidelines established for the study, areas that had a certain degree of homogeneity, which would allow the generation of statistical information with a lesser degree of internal discrepancy.

The result of the second step, "the pact stage," resembles what Perroux (1955) called planning regions, with the inclusion of administrative-political criteria. The goal was to make the regionalization proposal operational, not only from the point of view of production and dissemination of information, but also in its use as an area for planning actions and services for the population, even though such an option would mean a certain loss of homogeneity in the parameters used in the previous step.

\section{The shared management of Belo Horizonte}

The shared management model of Belo Horizonte at the time included more than 80 boards and committees of municipal, regional, and local scope. In addition to the 25 thematic Public Policy Councils provided for by federal law, other collaborative structures had been created as a result of governmental or popular proposals. These structures integrated the "participation network" of the city, ensuring a degree of transparency and accountability in the management of public policies and in proposing initiatives. The approach that was to be adopted in the territories initially followed a bottom-up composition; it provided authority for the regulation and control of public policies, and for proposing the initiatives and policies to be implemented in each area.

It is important to note that in the preceding decades, the different governments of Belo 
Horizonte had maintained some continuity in creating different intra-urban territorial planning scales adaptable to the challenges of contemporary public life. Almost every aspect of the urban routine makes clear the way reality manifests itself —and requires answers-on multiple political, economic, and therefore territorial scales. The near and the far, the site and the non-site do not come together and mingle without annulling each other in every aspect of everyday life. This is why the answer to social demands requires the use of multiple scales of planning and action; in other words, multiple territorial clippings and the institutional arrangements associated with them can address specific problems and give appropriate responses.

Thus, the nine administrative regions existing in the city today were created during the 1970s and 1980s. Since 1995, the municipal government and the territorial planning departments of Belo Horizonte have incorporated the concept of homogeneous areas. In this period, the Master Plan resulted in the division of the city into 81 Planning Units (Ups) (Amaral, 1999). In 2000, some UPs were aggregated into larger units creating the sub-regions, sub-regional distribution, and discussion of resources in the Participatory Budget, or OP as it is called (Filizzola, 2003).

As the territorial delimitation of both UPs and the OP sub-regions were based on the concept of homogeneity, the creation of Shared Management Territories can be seen as a further step in the enhancement of territorial planning scales although with its own differences.

First, the special divisions of Belo Horizonte around the UPs and sub-regions designed in 1995 were not always consistent with the homogeneity criterion, given the non-linear growth of the city over the past two decades, the emergence of new centers with vectors of strong economic and urban expansion in some areas, and the cooling of growth in other regions. Second, the review in early 2011, within the limits of administrative regions, introduced by Municipal Law 10.231, meant that the homogenous areas that existed prior to approval of this law were no longer entirely in a single region. Third, it was essential that the homogeneous areas followed the boundaries of the neighborhood layers agreed by $\mathrm{PBH}$ and the Brazilian Institute of Geograpgy and Statistics (IBGE) in 2008 and 2009 in order to maximize the use of census data of 2010, including the sample data.

If, from a technical point of view, the new regionalization meant territorial review of a concept already applied by the municipal government in its planning-homogeneous areas-from the political point of view, the proposed spatial organization was radically innovative: it was designed to be used and absorbed not only by the government and its technical staff, but by citizens, in a joint process between government and civil society intended to deepen the knowledge of the city. Statistics, indicators, and georeferenced data produced by the government related to the multiple urban, social, and economic realities of these territories, as well as information on current investments that were to have their access democratized. Such data was to be organized for each homogeneous area and made available not only for the city government, but also for citizens in a process that would allow local government and civil society to have a better understanding of the prob- 
lems and intra-urban needs. The availability of information was a fundamental part of the dialog that was planned between these segments in order to plan the city. In this sense, the intended institutional use of regionalization of the Shared Management Territories was to bring together local government and citizens in neighborhoods sharing a similar quality of life, to discuss the city and the government's performance, and to collectively build public policy and plan Belo Horizonte. This project, initially given the name of "Radicalizing Democracy," gave rise in 2011 to the "Participatory Regionalized Planning." Its goal was to increase direct social participation in the public policies of Belo Horizonte through participatory planning, and guarantee the production and dissemination of knowledge about the city by focusing on the characteristics and problems of each homogeneous area (the Shared Management Territories).

It is important to emphasize that the scenario in which it was possible to implement the 2011 Participatory Regionalized Planning project was part of a trajectory of nearly two decades of progressive governments and democratic governance. All the municipal governments since 1993 supported mechanisms of direct and semi-direct participation to allow the continuous monitoring of public policy issues by organized society in the intervals between electoral periods.

\section{Guidelines for regionalization}

The guidelines set for the regionalization of Belo Horizonte focused on categories that included economic, social, urban, geographical, and political issues:

- Internal homogeneity;
- Territorial contiguity;

- Minimum population size of 40,000 inhabitants;

- Observance of the limits of regional administrations (Law 10,231/2011) and neighborhood boundaries (map version neighborhoods of Law 9,691/09, updated to the 2010 Census);

- Use of neighborhoods as the minimum geographic units of aggregation;

- Total number of subdivisions around the city of Belo Horizonte between 35 and 45 areas;

- Ease of mobility, considering the physical barriers created by major routes (avoiding disconnector elements such as physical barriers or major roads within the territories);

- Knowledge of the territory and of the relations within it; and

- Perception of belonging by the population.

These guidelines were initially proposed by the technical coordination of the regionalization project and then debated and agreed upon within the wider municipality, especially the sectors that had been most involved in the debate.

The Skater Tool Application to Belo Horizonte

In order to meet the proposed objectives, a statistical technique was used to generate conglomerate areas that show a greater internal homogeneity given their predefined attributes and, at the same time, were heterogeneous to each other. The technique used is based on the method of a Minimum Spanning Tree and is implemented in the Skater tool "Spatial Cluster Analysis" by Tree Re- 
moval Edge. This tool was developed in the Laboratório de Estatística Espacial (LESTE) [Spatial Statistics Laboratory] of the Federal University of Minas Gerais, and is also available in TerraView. The regionalization model built in the application, and based on predefined variables, takes into account the spatial location of objects, allowing contiguous areas with similar characteristics to be gathered in the same space conglomerate. The spatial units considered in the composition of conglomerates were the 487 neighborhoods of Belo Horizonte city. A neighborhood matrix was generated by considering the adjacency between the districts.

The choice of the variables to characterize the homogeneity of the clusters was based on the availability of data about intra-urban aspects, the possibility of estimating the situation in the different neighborhoods of the city, and the need to represent various aspects of living and housing in the city. Three variables were used:

i) The Environmental Health Index [Índice de Salubridade Ambiental (ISA)] considered the conditions of water supply, sewage, garbage collection, urban drainage, and vector control.

ii) The Health Vulnerability Index [Índice de Vulnerabilidade à Saúde (IVSaúde)] considered the conditions of sanitation, housing, education, income, and health, and the characteristics of the head of household.

iii) The average market value of the built square meter was calculated from the real estate cadaster (IPTU) for houses located in each neighborhood.

The variables were standardized with the following formula:
Standard value $=($ Variable value in the neigh borhood - Average variable in the Regional ) / Standard Deviation in the Regional

Two proposals of regionalization were constructed that considered different parameters, the first with a minimum of 40,000 in each cluster, and the second with 50,000 inhabitants. The conglomerates generated also took into consideration the limit of the local regional administration in which the neighborhood was located.

\section{The Pact of Shared Management Territories}

Considering the results of the two conglomerate maps of Belo Horizonte resulting from the Skater method, the limitations of the technique adopted were not all measurable given the guidelines for the concept of homogeneous areas that the $\mathrm{PBH}$ wished to adopt. Moreover, given the interest of the municipal public administration in considering the maps and previous proposals for regionalization still in use by the planning secretariat, there was no doubt about the need for a second stage methodology to achieve the final proposal for the final spatial distribution of Belo Horizonte.

Among the issues not raised by the Skater, but fundamental to the definition of each territory, are guarantees of the absence of physical barriers that stop or reduce circulation, good mobility, and the inclusion of subjective criteria; the latter includes the residents' feelings of belonging to the territory, aspects of perception and understanding of the relationships geographically established (or nonexistent), and future prospects, even concerning the areas of demographic and economic 
expansion.

It was decided that this more subjective and perceptive information should be added to the objective and quantifiable criteria (already considered in technical studies), and both should guide the preparation of the Final Map for the Regionalization of Belo Horizonte. This process of reconciliation involved four proposals.

i) Preparation and assembly of four proposals to be considered

a) Sub-regions of the participatory budget: This proposal was prepared in 2000 and 2002, according to planning units, based on homogeneity criteria verified at the time of preparation; it was used as a territorial basis for resource allocation and organization of the participatory budget in the regional administrations of the city.

b) Maps prepared by regional administrations: The concept of homogeneity, in this case, is built by the regional administrators and their staff, from their knowledge of the area under management; the aspects considered were geographical barriers, mobility, circulation and social relations, and the residents living together. These proposals were prepared in 2010 as part of the city's regionalization work in Shared Management Territories.

c) Homogeneous areas with a minimum of 40,000 inhabitants produced in the Skater study.

d) Homogeneous areas with a minimum of 50,000 inhabitants produced in the Skater study.

The next step dealt with the challenge of building a single map from the four previously assembled maps (with similar but not identical proposals). The guiding principle of this construction was consultation and decisions by consensus. The dynamics of consultation first involved meetings of government actors, and then meetings of non-governmental actors to prepare the final, agreed version of the Shared Management Territories Map.

ii) Preparation of the consensus map of homogeneous areas of Belo Horizonte

The discussion with the population was held during workshops in 2011, which gathered the Municipal Executive and social leaders for the process of "Regionalized Participatory Planning" (PPR), held at the regional level and in each of the homogeneous areas. This process led to revisions in the proposal and gave rise to the 40 homogeneous regions of the Shared Management Territories Map (Territórios de Gestão Compartilhada) that was institutionalized in PBH by Decree no.14,724 of December 20, 2011.

We can probably consider the city of Belo Horizonte in 2011 as a place where the link between local development and the deepening of democracy at the base of society (Silveira, 2010) had been strengthening for two decades. The municipal administration that governed the city between 2009 and 2012 using the spatial distribution of Shared Management Territories confirmed the thesis that development is associated with the radicalization of democracy as the basis of society.

The premise that supports this association between local development and strengthening participatory democracy, and provides greater possibilities for society to formulate and influence issues often reserved for gov- 
ernments is that society's view, although different in nature from that of the State, can contribute to the formulation of public policy. To be able to listen to the population about the impacts of the implementation of public policies in their daily lives, and their real needs can reveal the need for adjustments in policies or even the creation of new development strategies. In other words, knowledge and diagnosis of problems and design of answers also implies dialog with society, and with the social and popular movements that have multiple scales of debate, representation, and interests.

Added to all this, more information on how the population perceives public services and areas of State action can be a key element for the effectiveness of public policies. In this sense, we know that public policies formulated by the State, although often effective as answers to public demand, are sometimes not perceived as being so. The perception of citizens is of enormous value for the State to go beyond a good service that increases wellbeing to reach target audiences, and provide them with the feeling that they can have positive expectations about the performance of state bodies.

Territorialization by regionalization that gives visibility to the various local realities seems to contribute to public participation activities in an environment marked by unequal power relations. The relationship between the territory and popular participation occurs by means of the empowerment of local actors in the dynamics of planning and managing city development. In this relation between democracy and local development, spatial distribution related to the Shared Management Territories strengthens the effort to de- mocratize information and knowledge about the economic and social urban realities of the city of Belo Horizonte as a key input for democratic planning processes. Ending the monopoly of information provides society with the conditions to understand and evaluate the results being achieved by local government and a basis on which to build consistent arguments for their demands.

This strategic use of information, knowledge, indicators, and statistics in order to construct an integrated and systemic view of Belo Horizonte, includes all of the city's actors. When dealing with the question of what information to rely on to promote participatory planning and decisions about public investment, the government can share data that expresses local realities about the existence, quantity, and quality of public infrastructure and services, and their real effectiveness in the population. It can provide data that quantifies intra-urban inequality from the point of view of access and distribution of urban services. In addition, there is the commitment that the data from each of the Shared Management Territories can be easily understood by citizens, and be useful and upgradable over short periods of time. In Brazil, there are very few municipal databases that are able to update information between the ten-year national demographic census periods. This scarcity also highlights the broader importance of the local database now available for $\mathrm{PBH}$ for intra-urban diagnostics.

\section{FINAL CONSIDERATIONS}

This article analyzed Belo Horizonte's process of regionalization in "Shared Management Territories" to evaluate its results. Brazilian public policy was explored from the 
perspective of the articulations between government, private sector, and civil society; innovative mechanisms of democratic participation and the capacity of the Belo Horizonte process to create new participatory instruments and politics (Halpern et al., 2014; Spink, 2014) were discussed.

It seems clear that the initial objective of the regionalization of Belo Horizonte in Shared Management Territories - to gather homogeneous groups to deepen the understanding of the city and plan it collectively-resulted in the PPR, a process initiated in June 2011. The regionalization, the use of a scale that subdivides the city, enhances the identification of living conditions in each site and discloses the spatial inequality within the urban fabric - in terms of availability and access to urban infrastructure and social, cultural, and economic services-revealing the most deprived areas of public investment. The observation of diversity among the different geographical areas of the city promotes the analysis and evaluation of regional policies.

The "Regionalized Participatory Planning" regulated by Municipal Decree 14.724/11, which also established the Shared Management Territories as intra-urban spatial reference units for municipal territorial planning, took place throughout a series of public meetings and discussions at the regional and territorial level (in the 40 Shared Management Territories), which gathered citizens and local government for medium- and longterm city planning. In addition to the PPR, the spatial regionalization of Belo Horizonte in Shared Management Territories was also used to guide decisions on other administrative actions of the Municipality of Belo Horizonte in 2011 and 2012.
Five years after its implementation, evidence of the continued use of this new approach to regionalization by the municipal government agencies in the areas of sectoral planning is not entirely clear. There are, however, indications that it occurs at least partially.

The government's intention to strengthen and use the Shared Management Territories as a major planning instrument for the city led to a number of applications by different municipal secretariats. For example, the municipality's ombudsman began to monitor citizens' demands and the effectiveness of complaints resolutions for each Shared Management Territory. Moreover, as an early appropriation of this new spatial planning by segments of organized civil society, a civil society organization began data collection and indexes calculation (related to life quality in Belo Horizonte) for each Shared Management Territory in 2012.

Five years on, we have evidence that the Municipal Secretariat of Finance has been using the Shared Management Territories Regionalization since 2014 for the redefinition of the Homogeneous Areas applied to the Real Estate Map for Land Transactions ("Planta de Valores Genéricas do Imposto sobre Transmissão de Bens Imóveis Inter Vivos"). In another area, the proposal submitted to the IBGE for the 2010 Census by the Municipality of Belo Horizonte was also based on the spatial distribution of the Shared Management Territories.

At a qualitative level, it is important to note that the spatial process of the city of Belo Horizonte under the Shared Management Territories involved technical and political for 
learning for local government. While it has improved the concept of homogeneous areas of the city in terms of data, it has also meant implementing a consensually-based dialog between the government and citizens, and taking into account the inhabitants' feelings of "belonging" as a criterion for delimiting each Shared Management Territory.

Finally, while it is important to emphasize that the degree of implementation over the subsequent years does not coincide with initial expectations, it is also the case that the institutional use of the Shared Management Territories signaled, from the beginning, a will for democratic mobilization. In this sense, besides diagnosing the problems and challenges of each territory in a democratic way, it would be essential to build in new tools that could guarantee budget investment priorities for the most vulnerable areas in intra-territorial competition for financial resources; this did not always happen. This is a clear limit on Belo Horizonte's governance model of Shared Management Territories and PPR as an affirmative action that benefits the poorest areas of the city. The active management of the territory should mean that the "excluded" areas are a priority for investment, and reaffirm a pact of social justice.

The use of the new territorialities in "radicalizing democracy" has also had its limitations. On one hand, the Regionalized Participatory Planning project ended up as a consultative and not deliberative body, as there was no specific budget allocation for popular decisions made in the PPR. Moreover, the proposal to share information with civil society was not maintained with the same degree of continuity. The meetings of the PPR and the update of data for each Shared Manage- ment Territory on the Internet (available at: http://gestaocompartilhada.pbh.gov.br/) were not regular after 2012.

Using a scale expresses the deliberate intention of someone to observe an object (Boudon, 1991). In this sense, one can say that the regionalization process of the city of Belo Horizonte reveals the intention of the municipal government to observe and better understand the city, its intra-urban particularities, and the possible languages of political action concerning the complexity of urban reality and plurality of actors. Based on the analyses, it can be reiterated that knowledge of the territories' different realities is an important tool for setting priorities, supporting territorial interventions planned in municipal public policies, and creating spaces for participation and new languages in public action. The continuation of this process involves expanding the capacity for active management of the territory, such as recognizing that vulnerable or "excluded" areas need to be prioritized to reduce social inequalities and improve the quality of life.

\section{REFERENCES}

Amaral, F. M. P. (1999). Definição de unidades espaciais de planejamento. Planejar $\mathrm{BH},(3), 7-12$.

Azevedo. S., \& Nabuco, A. L. (Orgs.). (2008). Democracia participativa: A experiência de Belo Horizonte. Belo Horizonte: Editora Leitura.

Boudeville, J. (1969). Los espacios económicos. Buenos Aires: Eudeba.

Boudon, P. (1991). De l'architecture à 


\section{PUBLIC ACTION AND THE CONSTRUCTION OF NEW URBAN TERRITORIALITY IN BELO HORIZONTE, BRAZIL}

l'épisttémologie. Le problème de l'échelle. Paris: Puf.

Ferreira, C. M. C. (1989). Espaço, regiões e economia regional. In: P. R. Haddad. (Ed.) Economia regional: Teorias e métodos de análise. Fortaleza: Banco do Nordeste do Brasil S.A.

Filizzola, B. (2003). 10 anos de Orçamento Participativo: A experiência de Belo Horizonte. Anuário Estatístico de Belo Horizonte, Belo Horizonte: Prefeitura Municipal de Belo Horizonte.

Halpern, C., Lascoumes, P., \& Le Galès, P. (Eds.) (2014). L'instrumentation de l'action publique. Controverses, résistance, effets, Paris, Presses de Sciences Po, collection "Gouvernances".

Hassenteufel, P. (2008). Sociologie politique: L'action publique, Armand Colin, collection. U "Sociologie".

Hirschman, A. O. (1958). The strategy of development, New Haven, CT: Yale University Press, [Cited from: Estratégia do Desenvolvimento Econômico. Rio de Janeiro: Fundo de Cultura, 1961].

Lascoumes, P., \& Le Galès, P. (Eds.) (2004). Gouverner par les Instruments. $1^{\mathrm{a}}$ ed. Paris: Presses de la Fondation Nationale des Sciences Politiques.

Lascoumes, P., \& Le Galès, P. (2009). Sociologie de l'Action Publique. $2^{\underline{a}}$ ed. Paris: Armand Colin.

Le Galès, P. (2006). Gouvernement et gouvernances des territoires. Problemes poli- tiques et sociaux, n 922, avril, 2006.

Myrdal, G. (1957). Economic theory and underdeveloped regions. London: Duckworth. [Cited from: Teoria Econômica e Regiões Subdesenvolvidas. 3rd ed., Editora saga, 1972].

Nabuco, A. L., Ferreira, R. N., \& Almeida, M. C. de M. (2013). Territórios de Gestão Compartilhada na cidade de Belo Horizonte: descrição da metodologia utilizada e perspectivas de uso da nova regionalização. Retrieved from http://diamantina.cedeplar.ufmg.br/2012/ arquivos/Territ\%C3\%B3rios\%20de\%20 Gest\%C3\%A30\%20Compartilhada.pdf.

PBH-Prefeitura de Belo Horizonte. (2012). Caderno de Metodologias e Diretrizes do Orçamento Participativo 2013-2014, disponível in: http://portalpbh.pbh.gov.br/pbh/ ecp/files.do?evento=download\&urlArqPIc= Metodologia_e_Diretrizes_2013_2014.pdf. Acessado em Abril 30, 2012.

Perroux, F. (1955). Note sur la Notion des Poles du Croissanee. Economic Appliquee 1 and 2: 307-320, [Cited from: O Conceito de Pólo de Desenvolvimento. In J. Schwartzman, (Org.) Economia Regional: textos escolhidos. Belo Horizonte: CEDEPLAR, 1977].

Pires, L. H. (2010). A descentralização do poder e a regionalização das soluções: instrumentos de promoção do desenvolvimento local e regional. In: L. Dowbor, \& M. Pochmann, (Orgs.), Políticas para o desenvolvimento local (pp. 105-129). São Paulo: Editora Fundação Perseu Abramo.

Santos, M. (2008). O espaço dividido: os dois circuitos da economia urbana dos 
países subdesenvolvidos, 2nd ed. São Paulo: Editora da Universidade de São Paulo.

Silveira, C. (2010). Desenvolvimento local e novos arranjos socioinstitucionais: algumas referências para a questão da governança. In: L. Dowbor, \& M. Pochmann, (Orgs.), Políticas para o desenvolvimento local (pp. 41-65). São Paulo: Editora Fundação Perseu Abramo.

Spink, P. K. (2012). Processos organizativos e ação pública: as possibilidades emancipatórias do lugar. In A. M. Jacó-Vilela, \& L. Sato, (Eds.). Diálogos em psicologia social [online]. Rio de Janeiro: Centro Edelstein de Pesquisas Sociais, 2012. p. 352-369. ISBN:
978-85-7982-060-1. Available from SciELO Books <http://books.scielo.org >.

Spink, P. K. \& Alves, M. (2008). Hybrid arenas and the dilemmas of public action: Looking for a different bottom line. Paper presented at 2nd LAEMOS Colloquium, Rio de Janeiro, May, 2008.

Williamson, J. (1965). Regional inequality and the process of national development: $A$ description of the patterns. Economic Development and Cultural Change, 13: 3-45. [Cited from: Desigualde regional e o processo de desenvolvimento nacional: descrição dos padrões. In: Schwartzman, J. (org.) Economia Regional: textos escolhidos. Belo Horizonte]. 